Received 13.012017 Reviewed 21.03.2017 Accepted 19.04.2017

A - study design B - data collection C - statistical analysis

D - data interpretation

$\mathbf{E}$ - manuscript preparation

F - literature search

\section{An application of a water assessment and simulation model in the remediation of the eutrophication capacity of a tropical water system: Case study the Lake Obili in Yaounde (Cameroon)}

\author{
Gideon A. AJEAGAH ${ }^{1)}$ ABE $\bowtie$, \\ W. Victorien B. ABANDA ${ }^{2) A C F}$, George E. NKENG ${ }^{2)}$ DEF
}

\footnotetext{
1) University of Yaounde 1, PO Box 812 Yaounde, Cameroon; e-mail: ajeagahg@yahoo.com

2) National Advanced School of Public Works, Yaounde, P.O Box 510; e-mail: victorien_abanda@yahoo.fr, gnkeng@yahoo.com
}
For citation: Ajeagah G.A., Abanda W.V.B., Nkeng G.E. 2017. An application of a water assessment and simulation mod- el in the remediation of the eutrophication capacity of a tropical water system: Case study the Lake Obili in Yaounde (Cameroon). Journal of Water and Land Development. No. 33 p. 11-22. DOI: 10.1515/jwld-2017- 0014.

\begin{abstract}
Lake Obili is one of the most famous lakes in the city of Yaounde, Cameroon. Studies carried out in this lake showed that it was hyper eutrophic and therefore it represents a great danger because it is used for aquaculture, tourism and a suitable laboratory for hydro-biological engineering. It is thus very vital to restore this lake ecosystem that singles itself in the heart of the city of Yaounde. This can be greatly facilitated through the use of Water Quality Analysis Simulation Program (WASP) of the United State Environmental protection Agency (USEPA). The outcomes of the previous results obtained from EUTRO, a Subroutine of the WASP model specialised in determining eutrophication level have proven that the remediation of this lake can be achievable through the implementation of a wet dredging, the construction and restoration of a wastewater treatment plant, the implementation of environmental incentive policies and the arrangement of the access to the lake. The application of the model is a contribution to the scientific mastery of nutrient flow, lake functioning and possibilities of restauration of highly polluted tropical water bodies subjected to domestic and industrial pollution.
\end{abstract}

Key words: Africa lakes, modelling, pollution, water

\section{INTRODUCTION}

Man cannot consider nature as a museum, meaning that he must use its resources to develop himself. Nevertheless, it should do it in a way to insure that the next generation must access to resources too; that is sustainable development which globalise the development in the social, economic and environmental aspect [GUERIN, LIBAERT 2008].
The implementation of sustainable development is an equation which is not easy to solve because of the lack of finances [WACKERMANN 2008]. For this reason, the Global Environment Facility (GEF) which is an initiative of United Nation (UN) is open to sustain the financing of environmental friendly projects on a planetary scale [GEF 2013; 2015]. Unfortunately this fund is not enough to sustain all the needs of humanity across the globe, with the most urgent being 
the potabilisation of water and the adaptation of suitable engineering for wastewater treatment.

Even if the lack of finances is a hindrance to the implementation of waste water sewage system and treatment plants, other problems such as incivism and scarcity of appropriate environmental policies are common in the tropical zone in Africa. Thus, aquatic ecosystems like lakes become the receptacle of uncontrollable waste from the society [MADJIKI et al. 2013].

Cameroon, which belongs to a tropical zone is also affected by such problems. No matter the fact that it has specialised tools like the National Fund of Environment and Sustainable Development (NFESD), the problem still persist and degrade the environment exponentially. One of the manifest effect of this degradation on lakes is the so called eutrophication which is the pollution of continental water body through an excess of nutrient flow [DUNALSKA, WIŚNIEWSKI 2016]. Eutrophication is a major problem in water quality management. The subject of this study is the relationship between nutrient input, a variation of the bio-physico-chemical parameters in lakes and the appropriate restauration response of the lake in question [BECK 1982; DUNALSKA, WIŚNIEWSKI 2016]. AGENDIA et al. [1992] think that eutrophication of Lake Obili is mainly due to the reception of non-treated waste water from University Hospital Centre (CHU) of Yaounde and the University of Yaounde I Campus. In the same words, NKENG [1999] determined that the eutrophication of this lake is due to the non-treatment of waste water, absence of rain water sewage system and the disposal of garbage inside this lake. The complexity of physical, chemical, and biological processes in lakes has prompted the development of modelling as an instrument for providing a simplified, and hopefully more understandable, picture of the system. Modelling must be understood in a broad sense as a means of organizing and representing available information in a systematic and useful way. Models can serve as an aid to improve our understanding of lentic ecosystem and to guide us in further research on the outcome of human activities of urban water bodies. The main objective of this work is to characterize the trophic state of Lake Obili and to propose solutions for its remediation using WASP software.

\section{MATERIAL AND METHODS}

\section{SITE DESCRIPTION}

\section{Geographic localisation}

Lake Obili (Fig. 1) is located very close to the campus of the University of Yaounde I. It has for geographic coordinates $3^{\circ} 51^{\prime} 23.1^{\prime} ' \mathrm{~N}$ and $11^{\circ} 29^{\prime} 43.5^{\prime}{ }^{\prime} \mathrm{E}$ and a mean depth of $750 \mathrm{~m}$. The climate here is globally that of Yaoundé which evolves as follows: a long dry season from the middle of November to the middle of march; a short rainy season from the middle of march to the end of June; a long dry season from July to the middle of august and a long rainy season from the middle of August to the middle of November. Meanwhile that distribution changes with climate mitigations that affects the municipality of Yaoundé. This lake is also maintained by the Olezoa River and Lake Atemengue as presented in Photo 1.

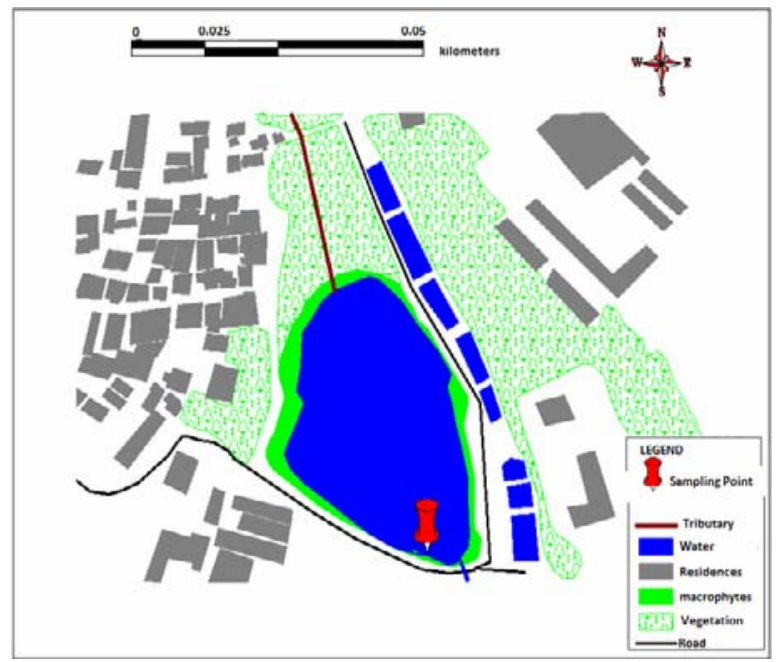

Fig. 1. Geographic information system of Lake Obili; source: own elaboration
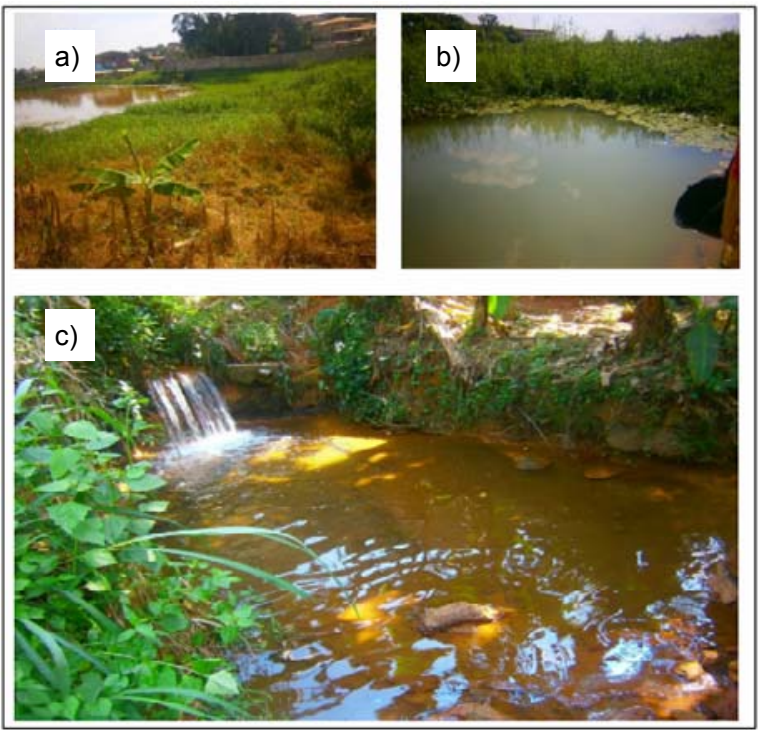

Photo 1. Lake Obili and its tributaries: a) Lake Obili emmisary, b) Lake Obili, c) Olezoa stream (phot. G.A. Ajeagah)

\section{Historical analysis}

From the works of AJEAGAH et al. [2013]: Lake Obili was created in 1948 by the Ministry of Water and Forest. It is in reality a wide pool derived from the Olezoa River. It has an ovoid form located at $3^{\circ} 51^{\prime}$ Nord latitude and $11^{\circ} 29^{\prime}$ East longitude. Initially, it has a depth of $1.80 \mathrm{~m}$ upstream, $2.5 \mathrm{~m}$ downstream and a volume of $15000 \mathrm{~m}^{3}$. Its activity mainly consists of providing eggs and fry for fish breeding and the experimental popularisation of fishing methods. This latter is made easy by a laboratory which synchronizes its activities with the ecosystem. 


\section{Contemporary situation}

Lake Obili breeds many species of fish, particularly two species of catfish: Chrysichthys nigrodigitatus and Heterobranchus longifilis which are omnivorous. This lake is also equipped by tools which help to evacuate the excess water. This may happen when the operator want to carry a great amount of fishes or to eliminate detrimental species.

\section{METHODOLOGY OF ANALYSIS}

In this part, we will describe exactly the procedure but also how data has been inserted in the software. The macrophytes which are aquatic plants that grow in or near water and are either emergent, submerging, or floating, were collected directly on randomly selected transects which are homogeneously distributed around the perimeter of the lake.

MapInfo professional 11.5 software was applied in the determination of the geometric parameters of Lake Obili. It is a powerful software for cartography and geographical analysis. It is fast, reliable and applicable in most ecological systems. It's more precise, productive and successful and presents a new interactive interface for thematic mapping.

\section{Water sample collection}

The water was carried out at the surface and the bottom of the lake at one sampling point. The samples were collected using Vandorn bottle (Photo 2) and stored in $1000 \mathrm{~mL}$ polyethylene bottles for preliminary analysis (field fixation) and laboratory analysis (laboratory determination).The euphotic layer was evaluated using the Secchi disc and the value measured in metres.

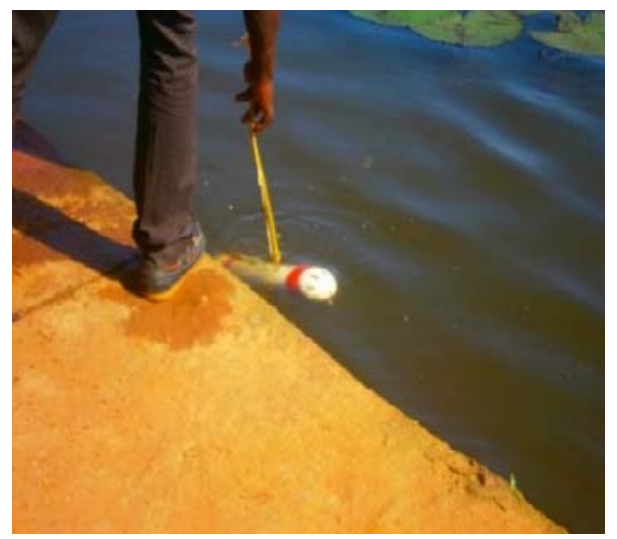

Photo 2. A scientist using Vandorn bootle's (photo. G.A. Ajeagah)

\section{Field fixation}

The aim of the field fixation was to avoid escape of $\mathrm{CO}_{2}$ and $\mathrm{O}_{2}$ concentration from the sampling water which could bias the results. For $\mathrm{O}_{2}$ fixation, $125 \mathrm{ml}$ of sampled water were insert in the Winkler bottle's and carefully closed such that interaction with the atmosphere is neglected. After this step, $1 \mathrm{ml}$ of manganese chlorine $\left(\mathrm{MnCl}_{2}\right)$ was added to the sample. A time of five minutes was require to keep the mixture stable. By the end, $1 \mathrm{ml}$ of Winkler reactant $(\mathrm{KOH}+\mathrm{KI})$ was added, the white milking precipitate confirm the success of the operation.

$\mathrm{CO}_{2}$ trapping was achieved using $20 \mathrm{ml}$ of $\mathrm{NaOH}$ $\mathrm{N} / 20$ introduced in a flask, containing $200 \mathrm{ml}$ of the sampled water. After this step, three drops of phenolphtaleine was added and the rest of space was completed by the sampled water. After field fixation, the samples were stored in ice boxes at $4{ }^{\circ} \mathrm{C}$ and send to the laboratory for further analysis.

\section{Laboratory determination of physico-chemical parameters}

- Determination of orthophosphate, nitrate, total suspended solid (TSS) and total dissolved solid (TDS) concentration

The concentration of orthophosphate and nitrate was determined using spectrophotometer DR3900 HACH LANGE. For this purpose, the latter was calibrated to $880 \mathrm{~nm}$ and $500 \mathrm{~nm}$ respectively for orthophosphate and nitrate. The process also required the use of Nitraver III and Phosver as reagents. Thus, 10 $\mathrm{ml}$ of them were inserted in the samples and $15 \mathrm{~min}-$ utes were required for the reaction to take place. At the end a blue precipitate confirm the success of the operation. The determination of TSS was performed using a spectrophotometer which was calibrated at $860 \mathrm{~nm}$ while a multiparameter was used for the determination of the TDS.

- Measurement of dissolved oxygen concentration

The determination of dissolved oxygen was performed according to the process described by APHA et al. [1998]. So, $1 \mathrm{ml}$ of concentrated sulfuric acid was inserted into the sample in order to dissolve the precipitate previously formed. The mixture was then introduced in an Erlenmeyer and two drops of starch (used as indicator) give a blue colour to the solution. The titration of the sample was performed using sodium thiosulfate $(\mathrm{N} / 80)$ which was introduce drop by drop in a graduated burette until full discoloration. The determination of dissolved oxygen was performed according to the formula given below:

$\left[\mathrm{O}_{2}\right]=($ first burette reading - second burette reading $) \cdot 2$

- Measurement of Carbon Dioxyde concentration $\left(\mathrm{CO}_{2}\right)$

The determination of concentration was also based on APHA et al. [1998] methodology. To achieve this, $50 \mathrm{ml}$ of the sample was titrated using $\mathrm{HCl} \mathrm{N} / 20$. The volumetric difference allows to find the $\mathrm{CO}_{2}$ concentration according the formula:

$\left[\mathrm{CO}_{2}\right]=($ first burette reading - second burette reading $) \cdot 17.6$

The witness was realised in the same condition like the sample but using distilled water. 
- Determination of carbonaceous biological oxygen demand

For measuring the carbonaceous biological oxygen demand after five days $\left(\mathrm{CBOD}_{5}\right)$, which is the quantity of oxygen required to decompose carbonaceous organic matter by microorganisms, a nitrification inhibitor was introduced in the sample. The mixture was then inserted into an incubator.

- Determination of morphometric parameters

The morphology of the lake was determined using the formulae:

$$
F=\frac{P}{2 \sqrt{\pi S}}
$$

Where: $P=$ perimeter, $S=$ the area of the lake.

When $F \approx 1$, the lake has an elongated form and when $F \quad 1$, the lake has a circular form.

The drainage density which is the ability of the watershed to drain the water owing to its shape was determined using the formulae:

$$
d=\frac{L}{S}
$$

Where: $L=$ the length, $S=$ the area of the watershed.

The mean slope $\left(i_{m}\right)$ was assessed using the formulae:

$$
i_{m}=\frac{1}{S} \sum_{i} L_{i} \Delta Z_{i}
$$

Where: $S=$ the area, $L=$ the length, $\Delta Z=$ piezometric level, $i=$ the number of interval between two piezometric lines.

That length and area were determined using MapInfo professional 11.5 and the piezometric lines were determined using google earth pro 7.5 version.

\section{Sampling of biological specimens}

Organisms were collected around the lake, in plastic bottles along the microhabitats of the lake ecosystem assessed. They were then transported to the laboratory of hydrobiology and environment for identification with the optical microscope. Macro-invertebrates were sampled with the help of a net of $30 \mathrm{~cm}^{2}$ at the end of a long handle. The sampling was carried out by a multi habitat approach as proposed by MOISAN [2010]. The organisms were stored in $10 \%$ formol on the field. In the laboratory, the samples were then put in $70 \%$ ethanol, and identified by optical microscope of marque IVYMEN, with the application of the identification keys of MOISAN [2010].

\section{Modelisation description program}

Water Analysis and Simulation Program is a software which simulates the quality of the water of a given ecosystem. To achieve this purpose it requires the use of model for eutrophication (Fig. 2). We use the sub model EUTRO incorporated in the WASP model which is specific to eutrophication. WASP can be applied to lakes, rivers and estuary. To apply this lake simulation model, we applied the results of the sample collected on the field as they are confirmed by the study of AJEAGAH et al. [2013] (Tab. 1). The start time for the simulation was 01.12.2012 and the end time was 01.06.2016.

The segmentation is one of the key point on WASP as it allows to personalise the studied system. Through this, intrinsic characteristics of Lake Obili were incorporated into the data. These characteristics were: the length, the width, the depth. So, the software MapInfo professional 11.5 was very useful as it enables us to find the variables characterizing the watershed. At the end, the parametrization allows us to create the segment called Obili Surf.

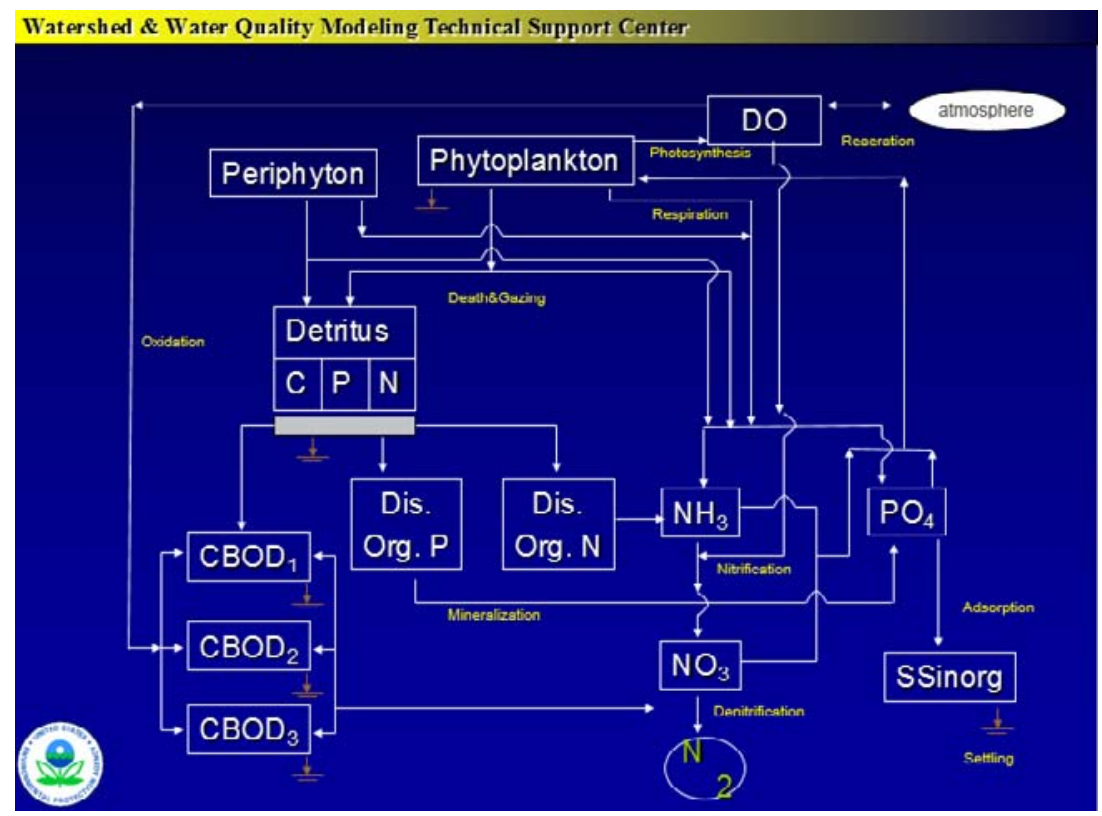

Fig. 2. Model for eutrophication used by WASP; source: USEPA [2015] 
Table 1. Results of sampling at Lake Obili from 01.12.2012 to 01.05.2013

\begin{tabular}{|c|c|c|c|c|c|c|c|c|c|c|c|c|}
\hline \multirow{3}{*}{ Parameter } & \multicolumn{12}{|c|}{ Value in month } \\
\hline & Dec. & Jan. & Feb. & March & April & Dec. & Jan. & Feb. & March & April & Dec. & Jan. \\
\hline & \multicolumn{6}{|c|}{ surface } & \multicolumn{6}{|c|}{ depth } \\
\hline $\mathrm{pH}$ & 7.20 & 7.26 & 6.74 & 6.40 & 6.60 & 7.02 & 7.00 & 7.02 & 6.72 & 6.53 & 6.71 & 6.58 \\
\hline $\mathrm{O}_{2}, \mathrm{mg} \cdot \mathrm{dm}^{-3}$ & 5.20 & 6.39 & 6.02 & 6.08 & 7.01 & 8.58 & 2.40 & 5.47 & 5.01 & 6.02 & 6.89 & 7.82 \\
\hline $\mathrm{CO}_{2}, \mathrm{mg} \cdot \mathrm{dm}^{-3}$ & 5.84 & 5.83 & 6.03 & 2.00 & 2.50 & 2.32 & 2.32 & 3.01 & 7.02 & 0.20 & 3.30 & 7.02 \\
\hline $\mathrm{BOD}_{5 \mathrm{mg} / \mathrm{LO} 2}$ & 60 & 40 & 70 & 80 & 110 & 70 & 160 & 120 & 170 & 90 & 80 & 30 \\
\hline $\mathrm{NH}_{3}-\mathrm{N}, \mathrm{mg} \cdot \mathrm{dm}^{-3}$ & 1.22 & 0.82 & 3.22 & 0.60 & 2.60 & 2.80 & 1.58 & 0.70 & 4.07 & 2.40 & 7.01 & 3.28 \\
\hline Nitrates, $\mathrm{mg} \cdot \mathrm{dm}^{-3}$ & 0 & 6 & 7 & 0.40 & 1.16 & 2.00 & 2.00 & 2.30 & 5.00 & 0.01 & 1.04 & 2.90 \\
\hline Nitrites, $\mathrm{mg} \cdot \mathrm{dm}^{-3}$ & 0.06 & 0.06 & 0.05 & 0.06 & 0.04 & 0.05 & 0.09 & 0.04 & 0.06 & 0.25 & 0.31 & 0.40 \\
\hline Phosphates, $\mathrm{mg} \cdot \mathrm{dm}^{-3}$ & 0.70 & 0.96 & 0.40 & 0.57 & 0.55 & 0.54 & 0.57 & 0.76 & 0.55 & 2.01 & 1.82 & 1.16 \\
\hline Alkalinity, $\mathrm{mg} \cdot \mathrm{dm}^{-3}$ & 8 & 6 & 4 & 4.3 & 2 & 8 & 0 & 92 & 2 & 3.7 & 1 & 8 \\
\hline $\begin{array}{l}\text { Calcium hardness, } \\
\mathrm{mg} \cdot \mathrm{dm}^{-3}\end{array}$ & 2 & 3 & 4 & 0.02 & 6 & 5 & 8 & 0 & 4 & 0.02 & 4 & 5 \\
\hline Colour Pt.Co & 28 & 36 & 98 & 29 & 19 & 37 & 11 & 94 & 126 & 49 & 23 & 37 \\
\hline
\end{tabular}

Source: AJEAGAH et al. [2013].

To simulate the behaviour of ultimate carbonaceous BOD (CBOD), CBOD has been identified as state variable, since it characterises the CBOD at the surface level. Taking the biodegradation rate constant $k$ as 0.23 which is the value common to many watershed, we expressed the UCBOD as follow:

$$
(\mathrm{UCBOD})=\frac{1}{0.68} \mathrm{CBOD}_{5}
$$

In WASP, the volume was computed using the formulae:

$$
V=z \cdot L \cdot l
$$

Where: $z=$ the depth, $L=$ the length, $l=$ the width.

The flow path was modelled through Obili_Surf according to Figure 3.

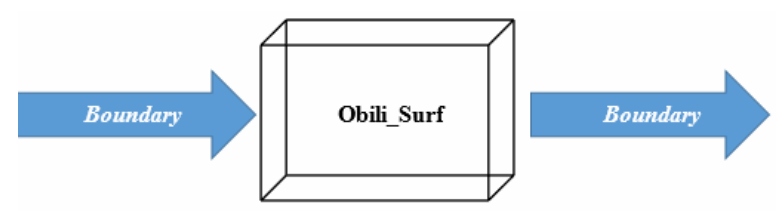

Fig. 3. Flow direction through Obili_Surf; source: own study

Concentrations at segment were put in order to compare results from simulation and observed ones. Thus, the efficiency test was performed, this was according the formulae:

$$
E F=1-\frac{\sum_{i}\left(y_{i}-\hat{y}\right)^{2}}{\sum_{i}\left(y_{i}-\bar{y}\right)^{2}}
$$

Where: $\hat{y}=$ simulated values, $y=$ observed values.

$E F \approx 1$ means that the prediction is perfect and the model run successfully, when $E F \approx 0$, the simulation is a failure. In that case, calibration is required in order to have more realistic results. Generally, the acceptable threshold value for efficiency analysis is 0.3 .

\section{RESULTS}

\section{TAXONOMIC COMPOSITION OF THE SITE AND BIOLOGICAL VARIABLES}

The site contains several macrophytes such as $V i$ taceae Cissus sp., Asteraceae Emilia praetermissa, Convolvulaceae Ipomoea alba, Commelinaceae commelina sp., Amarantaceae Amaranthus hybridus, Amaranthaceae Amaranthus viridise et Amaranthaceae Alternanthera, Nymphea lotus and Eichhonia crassipes (Photo 3a) which indicate that the water is subject to a high degree of contamination. The biological data is presented in the Table 2.
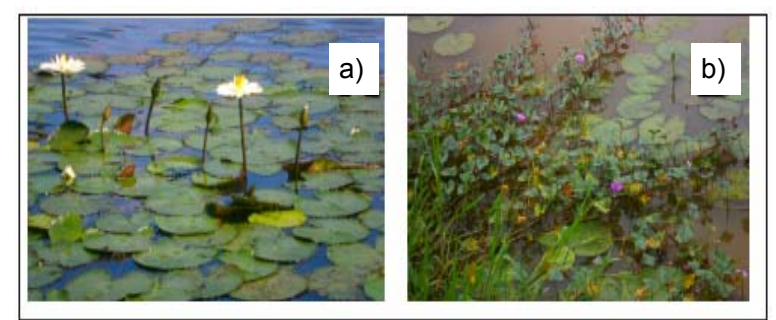

Photo 3. Some macrophytes of Lake Obili: a) Nymphea lotus, b) Eichhonia Crassipes (phot. G.A. Ajeagah)

Table 2. Biological variables evaluated in the Obili based ecosystem of Yaounde

\begin{tabular}{|l|c|c|l|l|}
\hline $\begin{array}{c}\text { Group of } \\
\text { organism } \\
\text { identified }\end{array}$ & $\begin{array}{c}\text { Total in } \\
\text { the rainy } \\
\text { season }\end{array}$ & $\begin{array}{c}\text { Total in } \\
\text { the dry } \\
\text { season }\end{array}$ & Indicator species & $\begin{array}{l}\text { Saprobity } \\
\text { indication }\end{array}$ \\
\hline $\begin{array}{l}\text { Ciliated } \\
\text { protozoa }\end{array}$ & 420 & 628 & $\begin{array}{l}\text { Paramecium } \text { sp, } \\
\text { Metpus, Caeno- } \\
\text { morpha }\end{array}$ & $\begin{array}{l}\text { hypereu- } \\
\text { trophe }\end{array}$ \\
\hline $\begin{array}{l}\text { Macroin- } \\
\text { vertebrates }\end{array}$ & 108 & 229 & $\begin{array}{l}\text { Physa, Cordula, } \\
\text { Nais, lunmbricus }\end{array}$ & eutrophic \\
\hline Total & 528 & 857 & & \\
\hline
\end{tabular}

Source: own study.

\section{GEOMETRIC PARAMETERS OF THE LAKE}

Using MapInfo professional 11.5, we found that the Lake Obili has an area of $11190 \mathrm{~m}^{2}$, a perimeter of $421.3 \mathrm{~m}$. Equations (1), (2) and (3), allow us to find 
that Lake Obili has a circular shape, a drainage density of $0.00136 \mathrm{~m}^{-1}$, and a mean slope of 0.0168 .

\section{PHYSICO-CHEMICAL PARAMETERS}

Results from the physico-chemical analysis (Fig. 4) reveal that TDS are found between $100 \mathrm{mg} \cdot \mathrm{dm}^{-3}$ and $150 \mathrm{mg} \cdot \mathrm{dm}^{-3}$, so these water are slightly mineralized. TDS concentration is greater in surface compare to the depth.

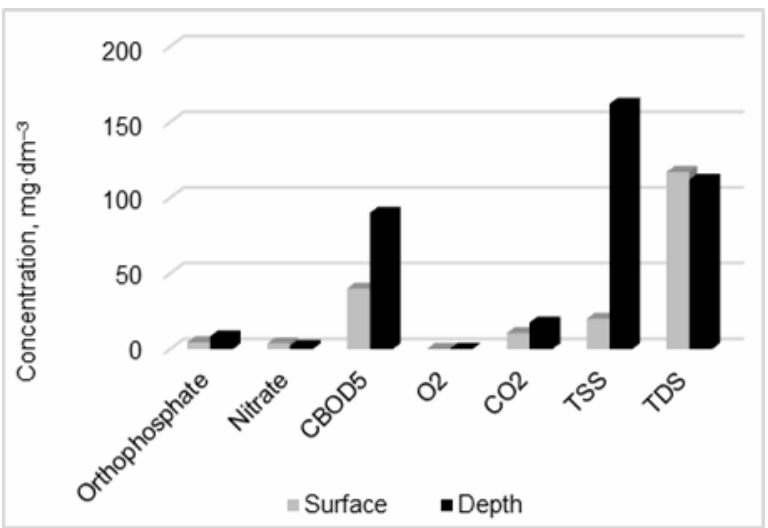

Fig. 4. Eutrophication parameters of Lake Obili; source: own study

Dissolved $\mathrm{CO}_{2}$ obtain a value of $10.56 \mathrm{mg} \cdot \mathrm{dm}^{-3}$ and $17.6 \mathrm{mg} \cdot \mathrm{dm}^{-3}$ respectively in the surface and in the depth. This variation is in adequation with $\mathrm{BOD}_{5}$ which takes the value of $40 \mathrm{mg} \cdot \mathrm{dm}^{-3}$ and $90 \mathrm{mg} \cdot \mathrm{dm}^{-3}$ and confirm a high bacterial activity in depth. Meanwhile, dissolved oxygen presents a very low values and is in conformity with the BOD and oxygen evolution.

Nitrate presents a value of $3.7 \mathrm{mg} \cdot \mathrm{dm}^{-3}$ which is greater than that observed in the depth $\left(2.2 \mathrm{mg} \cdot \mathrm{dm}^{-3}\right)$. This variation is in the antipodes of that of orthophosphate which takes the value of $4.46 \mathrm{mg} \cdot \mathrm{dm}^{-3}$ in the surface and $8.46 \mathrm{mg} \cdot \mathrm{dm}^{-3}$ in the depth.

\section{MODELISATION OF SOME EUTROPHICATION PARAMETERS USING WASP 7.52}

The Secchi disc reading was $0.5 \mathrm{~m}$ in the lake assessed, which represent the level of penetration of solar radiation. This depth is always assimilated to the euphotic zone. Forecast values has been found by applying EUTRO to Lake Obili and give the following results as presented in Figures 5-8.

Applying efficiency test, we found that the value for $\mathrm{DO}, \mathrm{UCBOD}_{1}$, nitrate, orthophosphate and ammonia were $0.99971747,0.4463593,0.99999489$, 0.9999922 and 1 which are globally close to 1 except the value of $\mathrm{UCBOD}_{1}$ which is 0.4463593 . Meanwhile, this represents an acceptable result since it is greater than 0.3 which is the minimum required for analysis.

From Figure 5, we see that ammonia concentration has a zigzag evolution. From December 2012 to April 2013. It takes it maximum value $\left(3.22 \mathrm{mg} \cdot \mathrm{dm}^{-3}\right)$ on 02.01 .2013 at $06: 30$ and a minimum value $(0.6$ $\mathrm{mg} \cdot \mathrm{dm}^{-3}$ ) on 27.01.2013 at 00:30. After April 2013, ammonia concentration has a constant value of 2.81 $\mathrm{mg} \cdot \mathrm{dm}^{-3}$. Meanwhile, this value is very harmful for fishes and can stimulate algal growth.

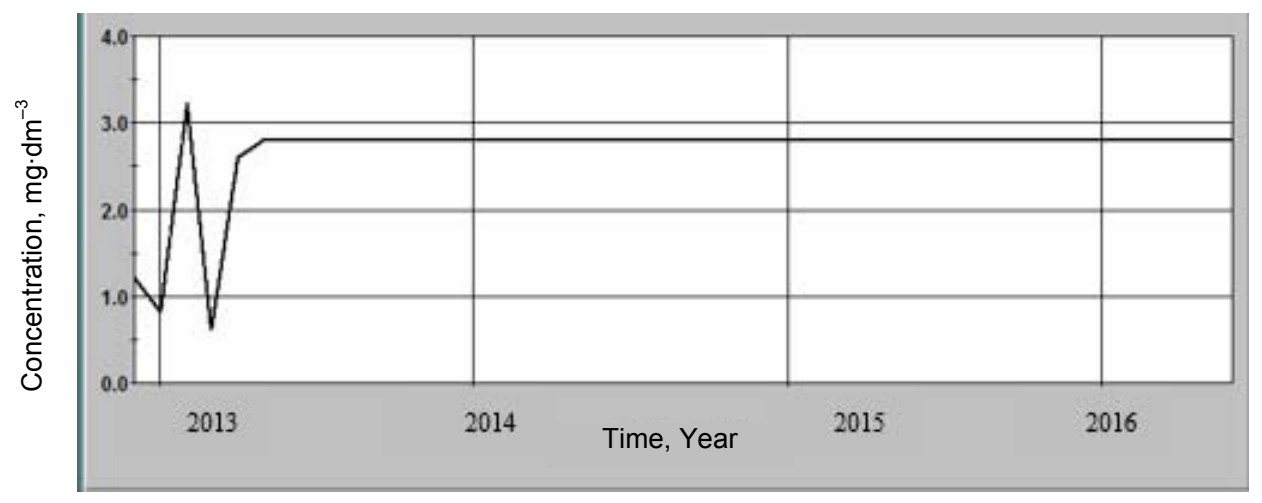

Fig. 5. Simulation of ammonia $\left(\mathrm{NH}_{4}\right)$ concentration measured and calculated by WASP; source: own study

The $\mathrm{UCBOD}_{1}$ varies slightly before 01.01.2013. This explain its linear shape. After this date, it evolves briefly in zigzag (end of the evolution on the 05.01.2013). It decreases linearly until August 2015 and keep stable until the end of the simulation around the value of $60 \mathrm{mg} \cdot \mathrm{dm}^{-3}$ which is harmful for the environment.

The Figure 6a that follow shows the variation of $\mathrm{UCBOD}_{1}$.

The concentration of DO (Fig. 6b) grows from 01.12.2012 to 01.01.2013; it has a slight inflexion followed by a growth until 02.05.2013 at 18:30. After this time, it has an abrupt decrease until 28.09.2015 at 06:30. This decreases is immediately succeeded by a linear growth until 26.11.2015 at 18:30, then by a constancy. At 2016 horizon, concentration get a stable value $\left(1.18 \mathrm{mg} \cdot \mathrm{dm}^{-3}\right)$. This situation is very critical because WASP predicts a very low DO value which can cause problems to local biocenose.

Nitrate concentration (Fig. 6c) grows until 01.02 .2013 at $06: 30$ where it gets the value of $7 \mathrm{mg} \cdot \mathrm{dm}^{-3}$; from this time, it has a decrease until the 
value of $0.41 \mathrm{mg} \cdot \mathrm{dm}^{-3}$ on 01.03 .2015 at 18:30. Immediately, it moves on with a linear growth until 30.09.2015 at 18:30. This growth is then followed by a stability (until the end of the simulation) which gives the aspect of a linear curve. This evolution allows to predict that nitrate contribution in the eutrophication process will be neglected. Consequently, its elimination is not primordial since at horizon 2016, its concentration will stabilise around $3.70 \mathrm{mg} \cdot \mathrm{dm}^{-3}$ which is very far from $10 \mathrm{mg} \cdot \mathrm{dm}^{-3}$ (value of water in excellent condition from nitrate point of view).
Orthophosphate concentration (Fig. 7) evolves as saw tooth with amplitudes that decrease until 01.02.2013. This variation continues with small and brief decreases and restart by a linear growth until 02.10.2015 at 06:30. From that period, the curve adopts an evolution that is almost constant until the end of the simulation. So, WASP predict that in the future, orthophosphate concentration will increase and will take values that have been never observed in the past. This chaotic situation shows that in Lake Obili, phosphate removal will be salutary.

a)

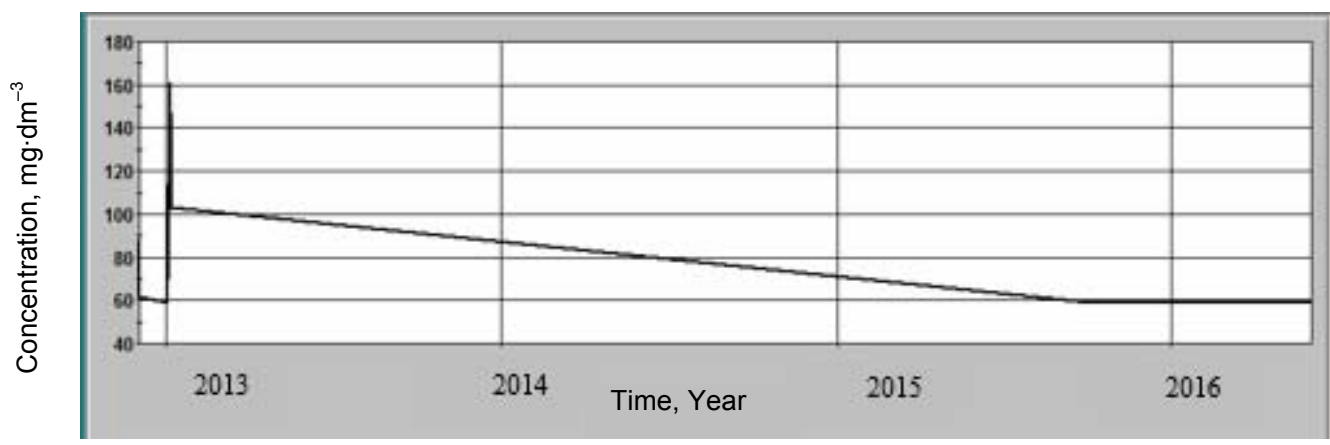

b)

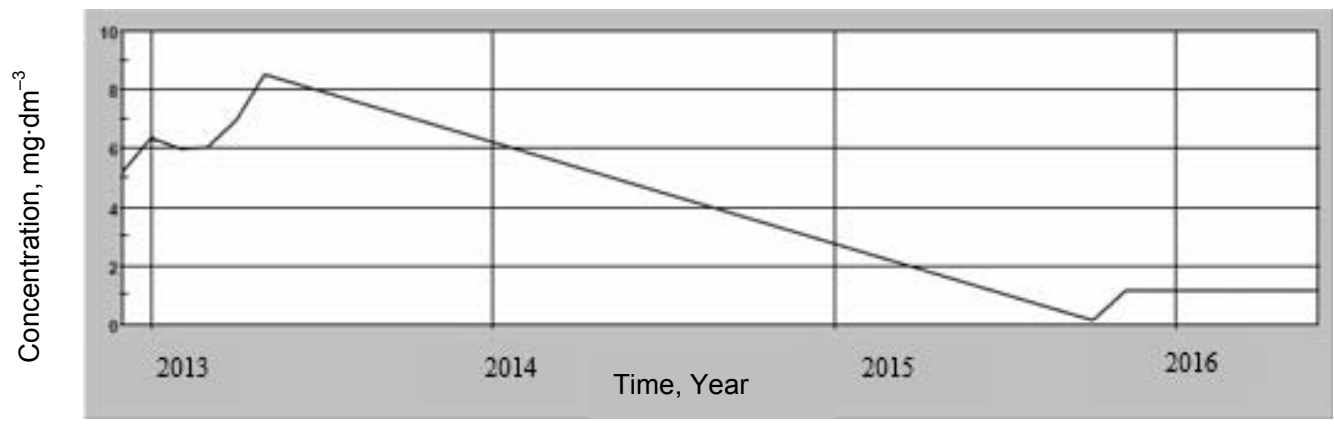

c)

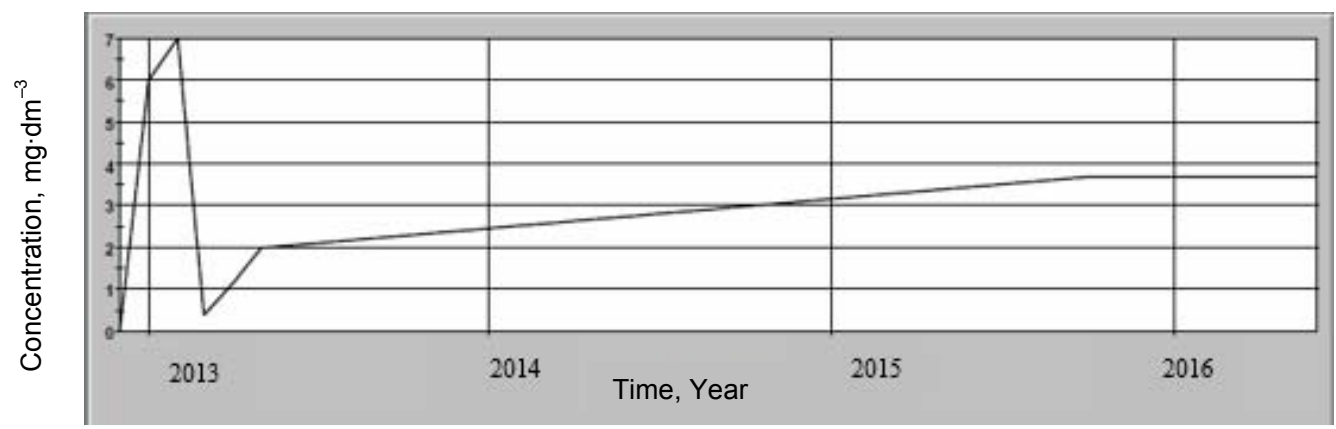

Fig. 6. Simulation of concentration measured and calculated by WASP: a) CBOD1U, b) DO, c) nitrate $\left(\mathrm{NO}_{3}\right)$; source: own study

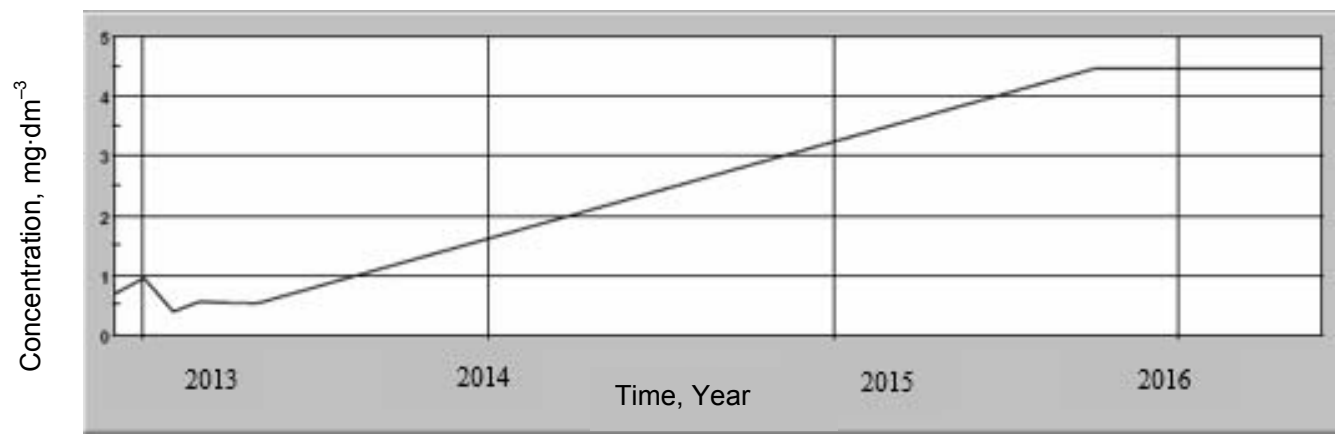

Fig. 7. Simulation of orthophosphate $\left(\mathrm{OPO}_{4}\right)$ by WASP measured and calculated with WASP; source: own study 


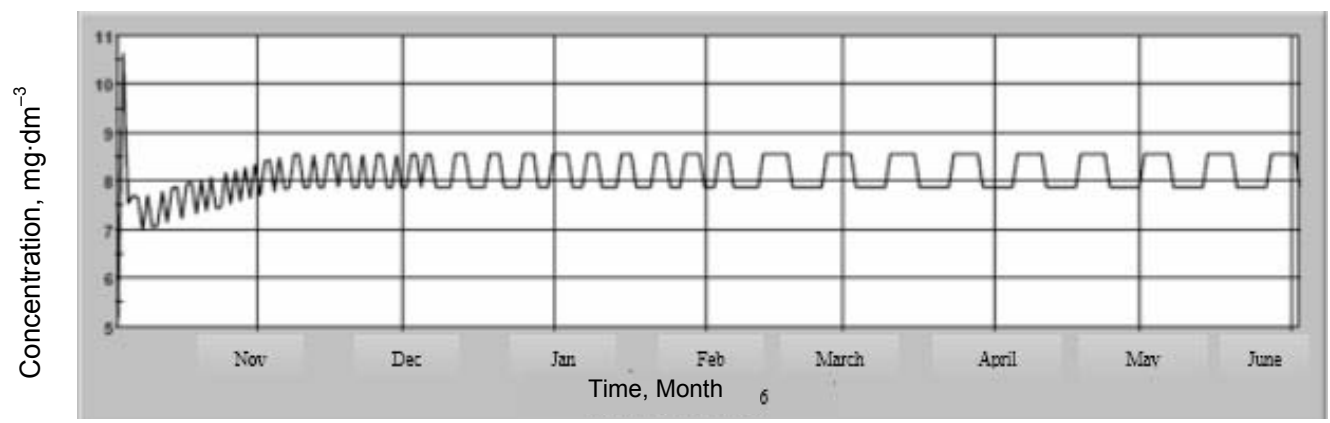

Fig. 8. Lake response after application of $45 \mathrm{t}$ oxygen daily (DO) load measured and calculated with WASP; source: own study

From the Figure 7, we have seen that in the future, anoxic conditions will be prevalent in this lake if nothing is done. Trying to avoid it, we perform oxygenation using WASP and we find that a daily load of $45 \mathrm{t}$ introduced from 01.10 .2015 was required to bring that concentration between 7 and $10.56 \mathrm{mg} \cdot \mathrm{dm}^{-3}$ (Fig. 8) which is the range for which aquatic life will flourish.

\section{DISCUSSION}

\section{INTERPRETATION OF PHYSICO-CHEMICAL PARAMETER RESULTS}

Sampling in Lake Obili show that the suspended solids are majority in depth in comparison with the surface. This is quite in conformity with results obtained from AJEAGAH et al. [2013]. This may be due to the perturbation of the media because of rains which motivate sediments resuspension. The use of Vandom bottle which can be in contact with the sediment during sampling process can also lead to have some sediments in the hypolimnion. Orthophosphate has such variation since it is highly elevated in the depth. This is because orthophosphate has a high affinity for sediments owing to its hight partition coefficient. Orthophosphate may originate from the use of detergents. This case was particularly observed in the Municipal Lake of Ebolowa by MADJIKI et al. [2013]. The temperature of water reduced with depth, since it has a low interaction with the atmosphere. This result is in conformity with that of PALMERI et al. [2014].

\section{DETERMINATION OF THE TROPHIC LEVEL}

Results from the sample analysis have shown that orthophosphate concentration is greater than 100 $\mu \mathrm{g} \cdot \mathrm{dm}^{-3}\left(0.1 \mathrm{mg} \cdot \mathrm{dm}^{-3}\right)$. On the other hand, the Secchi depth at the sampling point was $17 \mathrm{~cm}$. So using GALVEZ-CLOUTIER et al. [2002] classification, we conclude that Lake Obili is hypereutrophicated. This is also reinforced by the high pollution indicators (Tab. 3) and the data of the trophic level predicted by WASP (Fig. 5-8).
Table 3. Results from WASP simulation

\begin{tabular}{|c|c|c|c|c|c|}
\hline \multirow{2}{*}{ Date } & DO & BOD & Nitrate & $\begin{array}{c}\text { Ortho- } \\
\text { phosphate }\end{array}$ & $\begin{array}{c}\text { Am- } \\
\text { monia }\end{array}$ \\
\cline { 2 - 6 } & \multicolumn{5}{|c|}{$\mathrm{mg} \cdot \mathrm{dm}^{-3}$} \\
\hline 01.12 .2012 & 5.20 & 88.24 & 0 & 0.70 & 1.22 \\
\hline 01.01 .2013 & 6.40 & 58.74 & 6 & 0.96 & 0.82 \\
\hline 01.02 .2013 & 5.98 & 101.62 & 7 & 0.40 & 3.22 \\
\hline 01.03 .2013 & 6.04 & 100.38 & 0.4 & 0.57 & 0.60 \\
\hline 01.04 .2013 & 6.96 & 99.20 & 1.16 & 0.55 & 2.60 \\
\hline 05.01 .2013 & 8.51 & 97.68 & 2 & 0.54 & 2.80 \\
\hline 03.10 .2015 & 0.07 & 58.74 & 3.7 & 4.46 & 2.90 \\
\hline
\end{tabular}

Source: own study.

\section{RESTAURATION}

Predicted concentrations from WASP concerning orthophosphate, ammonia, and dissolved oxygen indicate that at 2016 horizon, eutrophication will intensify leading to macrophyte rising and death of numerous species [KEMKA 2000]. Meanwhile, the exclusive use of $45 \mathrm{t}$ (oxygen daily load) to rise DO level (Fig. 8) is an expensive choice and face to supplying and maintenance difficulties. Thus, it would be judicious to precede oxygenation by a substantial reduction of BOD which is achieved through sediment removal. For this fact, wet dredging appears as the better solution since it allows the removal of both sediments (which contain trapped phosphate) and sequestered gases avoiding by this fact the spread of nauseous odours.

Wet dredging will also be benefit for the health of the whole lake, since it will contribute to remove nitrate, and heavy metals sequestrated in sediments. Removed sediments will be treated (Fig. 9) and revalorise in agriculture where it can be used as fertiliser. The road should also be enlarged since wet dredging requires the use of big trucks.

This is illustrated by abandonment of the CHU treatment plant (Photo 4) which has no longer been replaced. So effluents are release from this station in Olezoa River which is a tributary water of Lake Obili. Thus, it is highly advice to restore this treatment plant. Elsewhere, Yaoundé city council can ensure the 


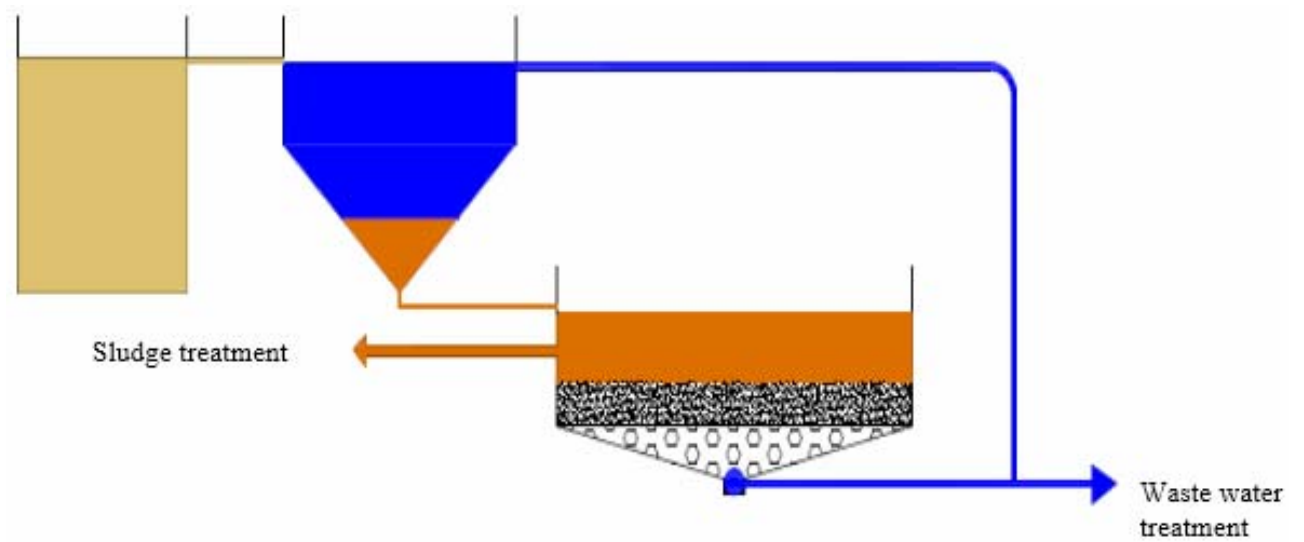

Fig. 9. Treatment of sediments; source: own elaboration

promotion and vulgarisation of decentralised systems (Fig. 10-14) through "solid waste management tax" exoneration for people which would adopt them. A vertical flow constructed wetland is a planted filter bed for secondary or tertiary treatment of wastewater such as greywater or blackwater that is drained at the bottom. Pre-treated Wastewater is poured or dosed onto the surface from above using a mechanical dosing system. The water flows vertically down through the filter matrix to the bottom of the basin where it is collected in a drainage pipe. The water is treated by a combination of biological and physical processes. The filtered water of a well-functioning constructed wetland can be used for irrigation, aquaculture, groundwater recharge or is discharged in surface water. To design a vertical flow constructed wetland, expert knowledge is recommended. They are relatively inexpensive to build where land is affordable and can be maintained by the local community. The important difference between a vertical and horizontal wetland is not simply the direction of the flow path, but rather the aerobic conditions existing in the treatment system, knowing the multiplicity of those systems, it would be judicious to base the exoneration on the degree of purification of the effluent. By building houses in the area to face the lakes, inhabitants in the a)

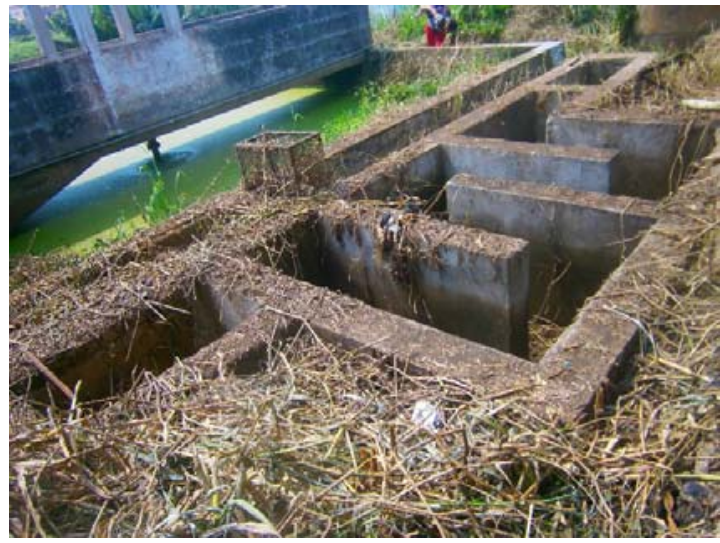

c)

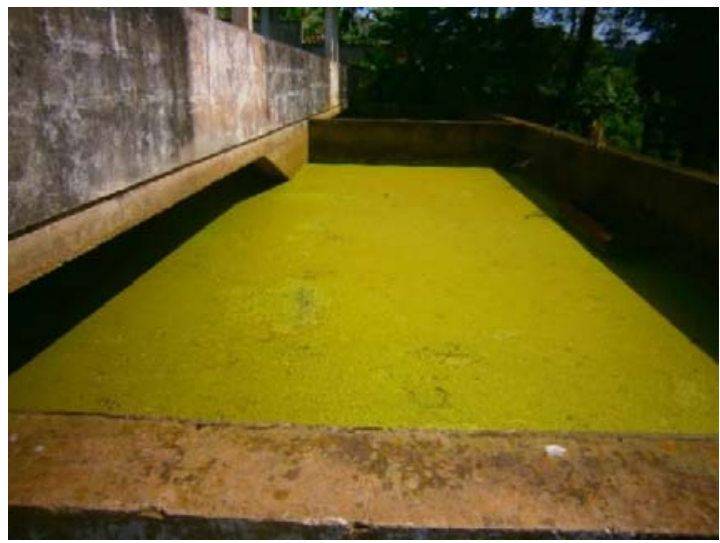

b)

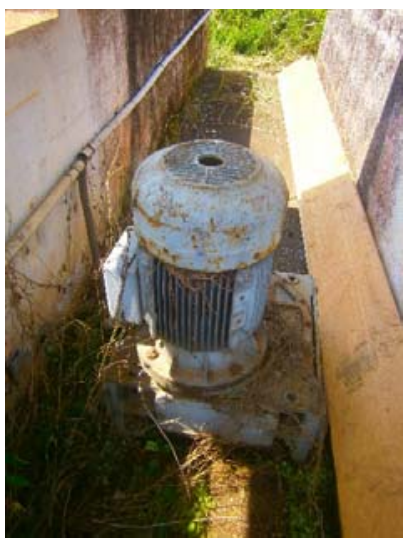

d)

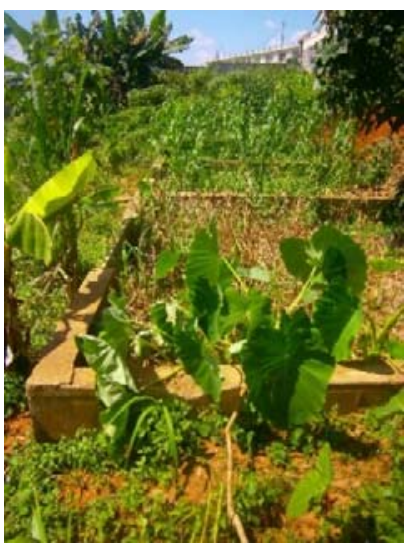

Photo 4. View of the abandoned treatment plant of CHU: a) pretreatment tank, b) turbine, c) aeration tank, d) sand bed; (phot. G.A. Ajeagah) 


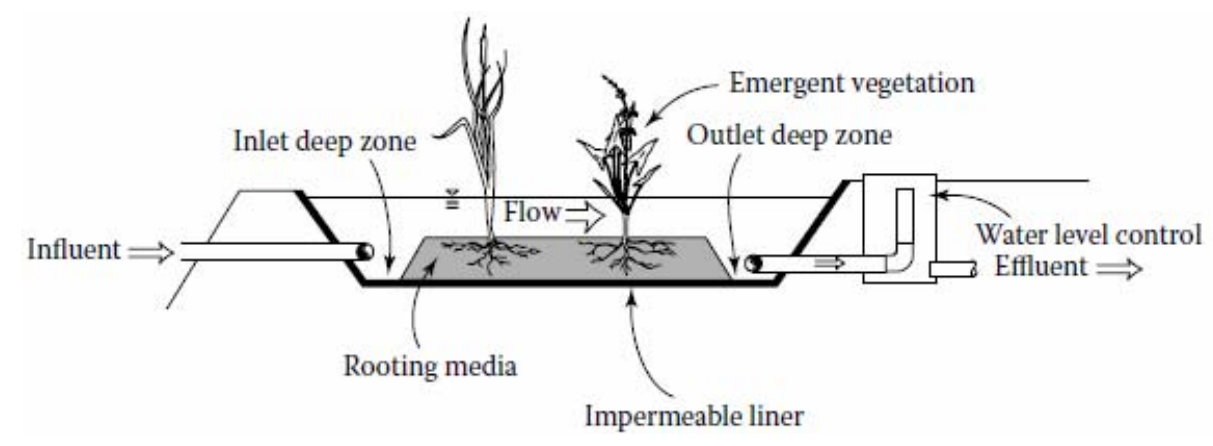

Fig. 10. Simple surface wetland; source: KADLEC and WALLACE [2009], modified

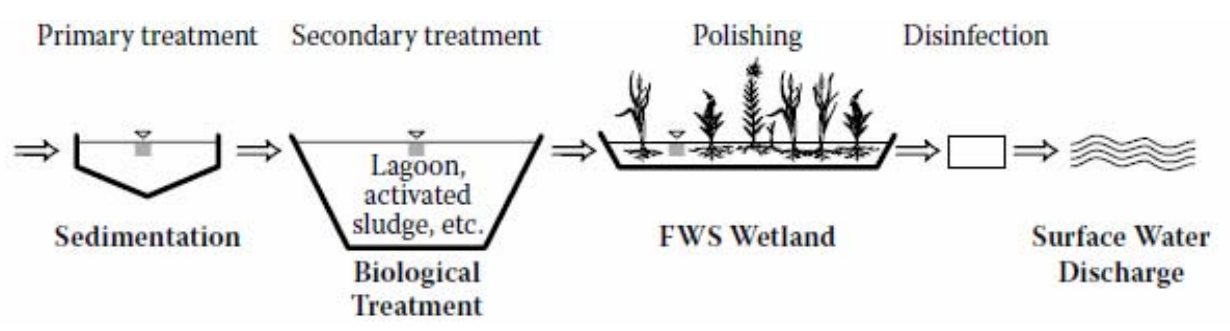

Fig. 11. Surface wetland and activated sludge; source: KADLEC and WALLACE [2009], modified

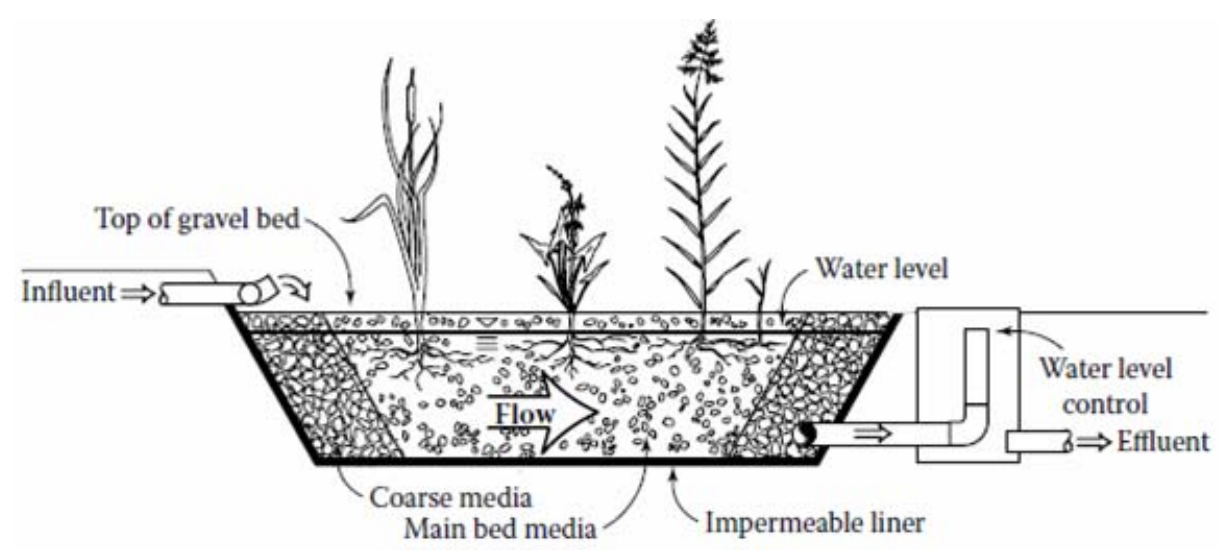

Fig. 12. Deep flow wetland; source: KADLEC and WALLACE [2009] adapted by Ajeagah et al

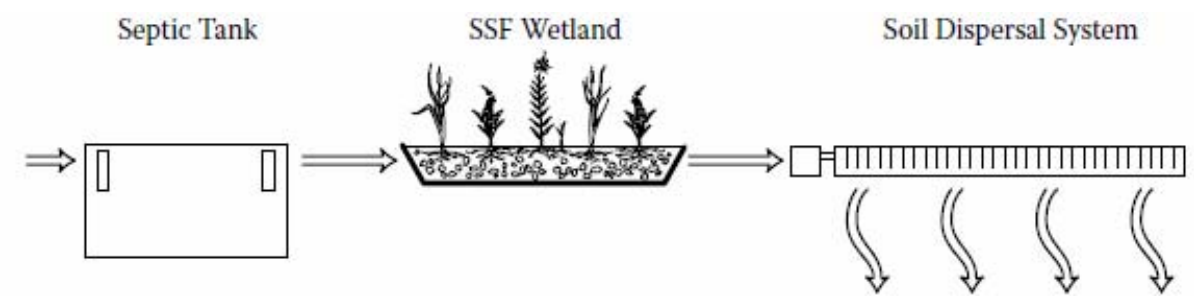

Fig. 13. Deep flow wetland and sceptic waste treatment; source: KADLEC and WALLACE [2009], modified 


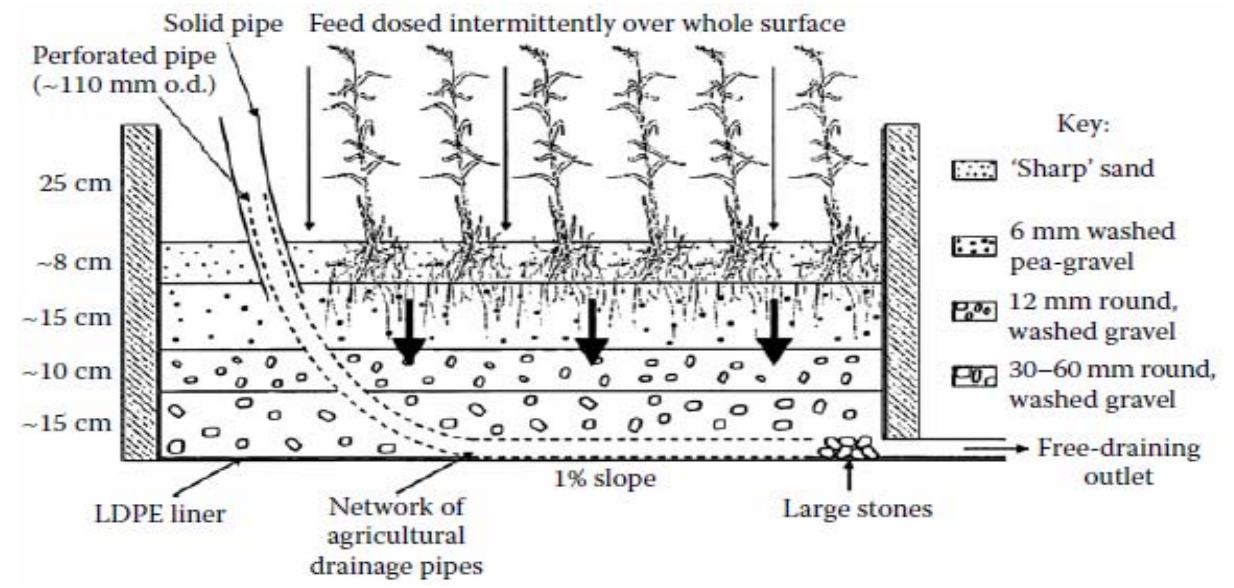

Fig. 14. Vertical flow wetland; source: KADLEC and WALLACE [2009], modified

neighbourhood will contribute to improve water quality by adopting environmental friendly behaviour. Since they will not support visual and olfactive pollution. It is also advisable to construct storm and waste water drainage systems directed towards a treatment plant. Yaounde city is developing its sportive infrastructures for the reception of the Women's African Cup of Nations of 2017 and the Men's African Cup of Nation of 2019. These events will contribute to bring a lot of tourists. The restoration of this lake will contribute to make the city more attractive and will promote safe fishing leading to poverty reduction. Cameroon emergence is in horizon 2035. Meanwhile, emergence is not only infrastructural or economic; it is also environmental and the restauration of this lake is a step in the right direction: that of sustainable development.

\section{CONCLUSIONS}

At the end of this study which consists of characterising an eutrophic lake and to apply WASP simulation model for its remediation, it has been found that this lake is hypereutrophicated revealing a high biodegradation of its components. The use of WASP was determinant in the forecasting of the evolution of concentrations and the determination of oxygen daily load that is necessary to restore this lake by rising the oxygen level. The solution can be summed up as: wet dredging, treatment of tributary water, management of wastewater treatment station, enlargement of the road as well as the promotion of decentralised and centralised systems. Meanwhile, it is important to notice in this case that the capital problem is not the absence of wastewater treatment plants, but their maintenance or adequation. The use of EUTRO the submodel specialised for eutrophication which is incorporated in WASP is particularly efficient in the determination of total maximum discharge load. Thus it is recommended for the treatment plants (centralised and decentralised) but also for the monitoring and design of the purification capacity of polluted tropical aquatic ecosystems.

\section{REFERENCES}

Agendia P., Fonkou T., SopKam T. 1992. Traitement des eaux usées provenant du Campus de l'Université de Yaoundé [Treatment of wastewater from the campus of the University of Yaounde 1]. Wetlands. Vol. 15. Iss. 4 p. 354-364.

Ajeagah G., Bikitbe J., Longo F. 2013. Qualité bioécologique d'un milieu lacustre hyper-eutrophisé en zone équatoriale (Afrique Centrale): Peuplement de protozoaires ciliés et macro invertébrés bentho-aquatiques [Bio-ecological assessment of a hyper-eutrophic lake in an equatorial region (Central Africa): Population dynamics of ciliated protozoa and bentho-aquatic macro invertebrates]. Afrique Science. Vol. 9. No. 2 p. 51-53.

APHA. 1998. Standard methods for the examination of water and wastewater. 20th ed. Washington. American Public Health Association, American Water Works Association, Water Environment Federation pp. 541.

BECK M.B. 1982. Identifying models of environmental system's behaviour. Mathematical Modelling. Vol. 3. Iss. 5 p. 467-480.

DunAlSKa J.A., Grochowska J., WiŚNIEWSKi G., NAPIÓRKOWSKA-KRZEBIETKE A. 2015. Can we restore badly degraded urban lakes? Ecological Engineering. Vol. 82 p. $432-441$.

DunALSKA J.A., WiŚNIEWSKI G. 2016. Can we stop the degradation of lakes? Innovative approaches in lake restoration. Ecological Engineering. Vol. 95 p. 714-722.

Galvez-Cloutier R., Ize S., Arsenault S. 2002. La détérioration des plans d'eau: Manifestations et moyens de lutte contre l'eutrophisation [Deteriration of streams: manifestation and restauration of Eutrophication]. Vecteur Environnement. Vol. 35. No. 6 p. 18-37.

GEF 2013. Qu'est-ce que le FEM? [What is the World Environment fund] [online]. [Access date 2010]. Available at: https://www.thegef.org/sites/default/files/ publications/aboutGEF-FR_3.pdf

GEF 2015. Instrument for the establishment of the restructured. Ed. 5. Washington. Global Environment Facility pp. 148.

GUERIN A., LiBAERT T. 2008. Le développement durable [Sustainable development]. Paris. Dunod. ISBN 978-210-051455-7 pp. 152.

KaDlEC R.H., WALlaCE S.D. 2009. Treatment wetlands. Boca Raton. CRC Press. ISBN 978-1-56670-526-4 pp. 1046. 
KemKa N. 2000. Evaluation du degré de trophie du lac municipal de Yaoundé: Etude du milieu, dynamique et structure du peuplement phytoplanctonique [Evaluation of the trophic status of the Municipal lake of Yaounde: Study of phytoplancton structure]. PhD thesis at thirth cycle of the University of Yaoundé I pp. 150.

Madjiki A.G., Pial A.-C., NdAm NgOupayou J.-R., AmouGOU A. 2013. Caractérisation hydrologique, morphométrique et physicochimique d'un hydrosystème urbain: Le lac municipal d'Ebolowa (Sud-Cameroun) [Hydrological, morphometrical and hydrochemical characterization of an urban hydrosystem: The Ebolowa municipal lake (South-Cameroon)]. Afrique Science. Vol. 9. No. 3 p. 1-3.

MoISAN J. 2010. Guide d'identification des principaux Macroinvertébrés benthiques d'eau douce du Québec, 2010. Surveillance volontaire des cours peu profonds
[Identification guide for the Macroinvertebrates in Quebec-Canada, Biosurveillance of shallow streams]. Quebec, Canada. Ministère du Développement durable, de l'Environnement et des Parcs. ISBN 978-2-55058416-2 pp. 82.

NKENG E.G. 1999. Sources and effects of water pollution in Cameroon. Eds. J. Dunlop, R. Williams. Glasgow.

Palmeri L., Barausse A., Sven ERIK Jørgensen 2014. Ecological processes handbook. Boca Raton. CRC Press. ISBN 1466558474 pp. 400.

USEPA 2015. WASP7 course [online]. [Access 27.08.2015]. Available at: https://www.epa.gov/ exposure-assessment-models/wasp7-cours

WACKERMANN G. 2008. Le développement durable [Sustainable development]. Paris. Ellipses. ISBN 2729839550 pp. 493.

\section{Gideon A. AJEAGAH, W. Victorien B. ABANDA, George E. NKENG}

\section{Zastosowanie symulacyjnego modelu oceny jakości wody w zapobieganiu eutrofizacji tropikalnych systemów wodnych: Przykład jeziora Obili w Yaounde (Kamerun)}

\section{STRESZCZENIE}

Jezioro Obili jest jednym z najbardziej znanych w mieście Yaounde w Kamerunie. Wyniki badań jeziora świadczą o jego skrajnej eutrofizacji, będącej poważnym zagrożeniem, ponieważ jezioro jest wykorzystywane w akwakulturze, do celów turystycznych, stanowi też laboratorium inżynierii hydrobiologicznej. Z tego powodu należałoby przeprowadzić rekultywację tego szczególnego ekosystemu jeziornego. Rekultywację jeziora może znacznie usprawnić zastosowanie programu analizy jakości symulacji wód (WASP) Agencji Ochrony Środowiska Stanów Zjednoczonych (USEPA). Wyniki poprzednich badań uzyskanych z EUTRO (podprogramu modelu WASP) wyspecjalizowanego w ocenie poziomu eutrofizacji dowiodły, że rekultywacja jeziora jest możliwa poprzez usuwanie osadów, budowę i unowocześnienie oczyszczalni ścieków, wdrożenie innowacyjnej polityki wodnej i zorganizowanie dostępu do jeziora. Zastosowanie modelu stanowi wkład w naukowe rozpoznanie przepływu pierwiastków biogennych, funkcjonowania jeziora i możliwości rekultywacji zanieczyszczonych zbiorników wodnych strefy równikowej.

Słowa kluczowe: jeziora Afryki, modelowanie, program WASP, woda, zanieczyszczenie 